H. J. KIM' ${ }^{1}$, M. H. CHOI' ${ }^{1}$ I. H. LEE ${ }^{1}$, S. P. HONG ${ }^{1}$, N. R. YOU ${ }^{1}$, H. S. KIM ${ }^{1}$, D. W. LIM ${ }^{2}$, and S. C. CHUNG ${ }^{1}$

\title{
COGNITIVE ABILITY AND CARDIOVASCULAR CONTROL IN INTELLECTUALLY AND DEVELOPMENTALLY DISABLED PEOPLE
}

\author{
Received April 10, 2013.
}

Earlier, we examined positive effects of hyperoxic air on the cognitive ability of intellectually and developmentally disabled people (IDDP). In this study, correlation between cognitive performance in the visual matching task and heart rate (HR) was investigated under normal air conditions. Eighteen men (mean age $28.7 \pm 5.0$ year) and 22 women (mean age $35.5 \pm 6.9$ year) with an assessed disability level of $2.3 \pm 0.6$ participated. The experiment consisted of three phases, a total of $7 \mathrm{~min}$, including the rest $(3 \mathrm{~min})$, control $(2 \mathrm{~min})$, and visual matching task 2 min phases. The HR in visual matching task phase increased, compared to those in the rest and control phases. The cognitive ability in the visual matching task correlated with the HR values; the response time showed a negative correlation with HR, while the accuracy rate showed a positive correlation. Thus, adaptive changes in cardiovascular regulation probably related to cognitive efforts and emotional excitation should be considered a noticeable factor influencing brain supply with oxygen in IDDP (similarly to healthy people). The result of this study agrees with the earlier obtained indications that hyperoxic air can positively affect the cognitive performance in IDDP.

Keywords: response time, accuracy rate, cognitive ability, heart rate, intellectually and developmentally disabled people.

\section{INTRODUCTION}

Intellectually and developmentally disabled people (IDDP) have difficulties in their social and personal life as a consequence of insufficient or incomplete intellectual development resulting from permanent retardation of physical and intellectual growth [1]. One of the most important characteristics of IDDP is a significant deficiency in the cognitive ability [1].

It has been reported that supply with high oxygen concentration exerts a positive effect on the cognitive ability of IDDP [2]. There was a decrease in the response time of a visual matching task in the presence of hyperoxic air (92\% oxygen) compared with normal air $(21 \%$ oxygen). When hyperoxic air was supplied, blood oxygen saturation $\left(\mathrm{SpO}_{2}\right)$ increased compared to that under normal air conditions. Thus, administration of hyperoxic air is one of possible approaches in

\footnotetext{
${ }^{1}$ Department of Biomedical Engineering, Research Institute of Biomedical Engineering, College of Biomedical and Health Science, Konkuk University, Chungju, South Korea.

${ }^{2}$ Department of Information and Communication Engineering, Dongguk University, Seoul, South Korea.

Correspondence should be addressed to S. C. Chung

(e-mail: scchung@kku.ac.kr).
}

clinical measures related to IDDP.

Many studies were performed using various verification methods in order to figure out the effect of supply of hyperoxic air on the cognitive ability of normal healthy people [3-15]. Hyperoxic air was found to enhance cognitive performance, including visuospatial $[7,10]$, memory $[9,12,13,15]$, verbal [4], n-back [6], and addition [8] tasks. Hyperoxic air improved cognitive ability by increasing the percentage of correct answers [4, 6-9, 12, 13] and/ or decreasing the response time [9, 10, 12-15]. Two main factors may be responsible for improved brain supply with effects oxygen; these are increased $\mathrm{SpO}_{2}$ and changes in cardiovascular regulation. A positive correlation was found between cognitive performance and absolute values of the heart rate (HR) and/or $\mathrm{SpO}_{2}$ in healthy young adults $[4,8,9,11,13]$. Functional magnetic resonance imaging (fMRI) studies showed that administration of highly concentrated oxygen increased the amount of neural activation due to the increase of oxygen supply to the brain area that is closely related to cognitive processing; due to this, there was an increase in cognitive ability $[3,5]$.

The positive effect of hyperoxic air on the cognitive 
performance of the IDDP was reported only in a single study [2]. Further studies using various verification methods should be done to exactly examine the effect of hyperoxic air on patients with cognitive problems like those in IDDP. From these, scientific evidences will be secured for clinical applications.

In our study, we tried to obtain a basis explaining positive effects of hyperoxic air on the cognitive performance in IDDP. As a stage in such studies, we investigated correlation between cognitive ability and HR values under normal air conditions, without administration of hyperoxic air. If we obtain increasing cognitive performance together with the increased HR, this means increasing of oxygen supply by faster blood circulation. Such a result should help to explain positive effects of hyperoxic air on the cognitive performance in IDDP.

\section{METHODS}

The participants of these tests were workers who were diagnosed with intellectual and developmental disability by a psychiatrist and who worked at a protective workshop of a community welfare foundation. Eighteen men $(28.7 \pm 5.0$ years $)$ and 22 women ( $35.5 \pm 6.9$ years; means \pm s.d. $)$ with an average assessed disability level of $2.3 \pm 0.6$ participated. They had no disease or abnormality in the cardiac and respiratory systems.

The experiment consisted of three phases for a total of $7 \mathrm{~min}$, including a rest phase ( $3 \mathrm{~min})$, a control phase ( $2 \mathrm{~min}$ ), and a visual matching task phase $(2 \mathrm{~min})$. The control phase corresponded to a stabilization period before starting the visual matching task. In this study, a visual matching task of a low level of difficulty was developed as a cognitive task for IDDP. Each item involved a simple cognitive task in which an identical figure on the left was selected from four examples. This task was a self-developed simple visual matching task similar to the visual matching task for the effect of administration of highly concentrated oxygen [10] and based on other tasks for simple visuospatial cognition studies [3, 7, 16-18]. During the visual matching task, 12 items were presented at 10 -sec-long intervals. The visual matching tasks were presented using E-prime (Psychology Software Tools Inc., USA). Items were presented on a monitor, and the subjects were asked to press the response button as quickly as possible via a keyboard to correctly identify the number of the item presented on the monitor. The response time and accuracy rate (number of correct answers/total number of problems $\cdot 100 \%$ ) in the visual matching test were calculated.

The HR was measured in min $^{-1}$ during all test phases using an 8600 series pulse oximeter (NONIN Medical, USA) on the participant's left index finger, and the mean HR value for each participant was calculated within each phase. The repeated-measures ANOVA (PASW ver. 18.0) was used for the phases (rest, control, and visual matching task) as independent variables to verify significant differences in the HR according to the phase. To investigate the correlation between cognitive performance and HR, Pearson correlations (PASW, ver. 18.0) were calculated to determine the relationship between the response time, accuracy rate of the visual matching task, and the HR value in the visual matching task phase.

\section{RESULTS}

The mean response time and accuracy rate were $3050.4 \pm$ $\pm 1057.5 \mathrm{msec}$ and $89.2 \pm 13.6 \%$, respectively. Figure 1 shows HR the means in each phase (rest phase, $76.6 \pm$ \pm 11.7 , control phase, $76.0 \pm 12.0$, and visual matching task phase, $78.4 \pm 13.1 \mathrm{~min}^{-1}$. There was a significant difference in the HR among the three phases $(P=0.001)$. As is shown in Fig. 1, the Bonferroni a posteriori tests revealed that the $\mathrm{HR}$ in the visual matching task phase increased significantly $(P<0.05)$, compared to those in the control and rest phases. As is shown in Fig. 2, the cognitive ability comparatively strongly correlated with the magnitude of the HR. The response time showed a negative correlation with the $\mathrm{HR}\left(\mathrm{r}=-0.456, \mathrm{R}^{2}=0.208\right.$, $P=0.003)$, and the accuracy rate showed a significant

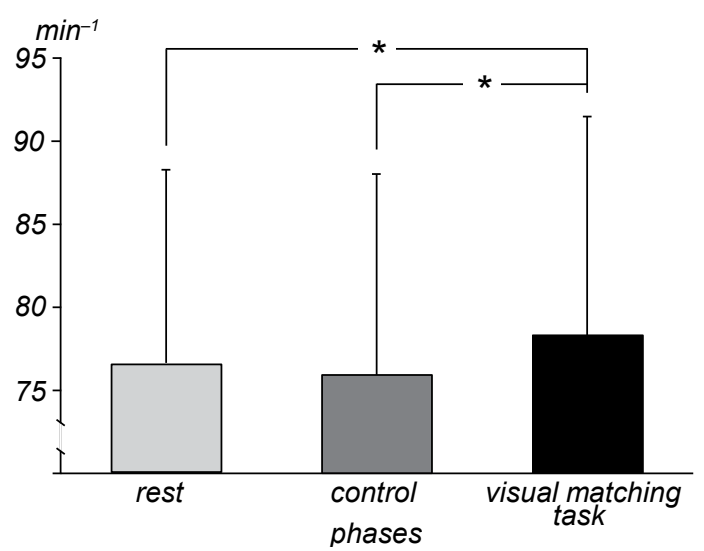

F i g. 1. Diagram of the mean values of the heart rate within three phases of the experiments. Means \pm s.d. are shown. Asterisks show cases of significant intergroup differences with $P<0.05$.

Р и с. 1. Діаграма середніх значень частоти серцевих скорочень у межах трьох фаз експерименту. 


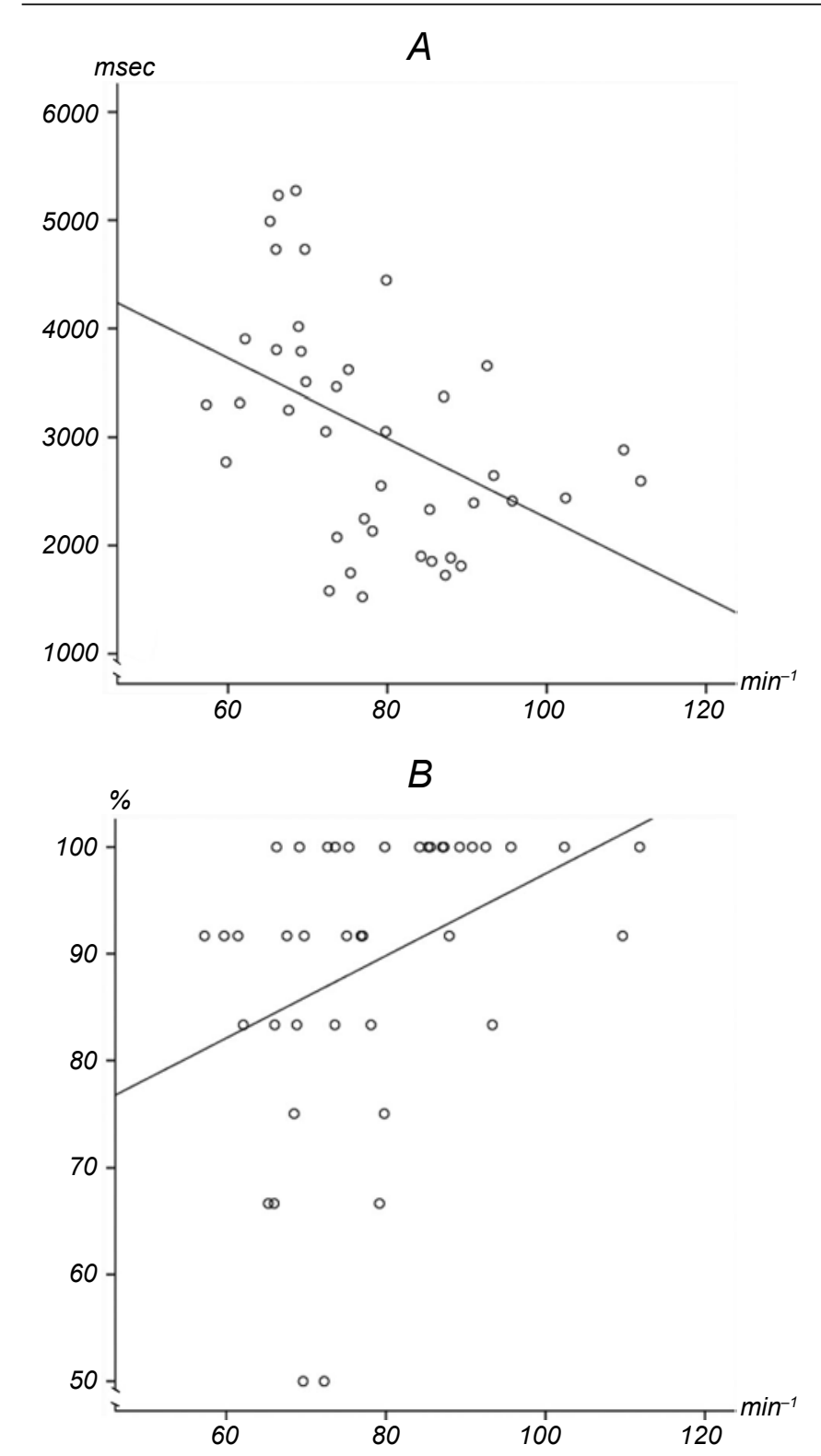

F i g. 2. Correlations between the response time (A, ordinate, msec) and accuracy rate $(\mathrm{B}, \%)$ of the visual matching task and the heart rate values $\left(\mathrm{A}, \mathrm{B}\right.$, abscissa, $\mathrm{min}^{-1}$ ) within the task phase.

Р и с. 2. Кореляція часу відповіді $(A$, мс) і рівня точності відповідей $(B, \%)$ у тесті візуального збігу зі значеннями частоти серцевих скорочень $\left(A, B, \mathrm{xB}^{-1}\right)$.

positive correlation with the $\mathrm{HR}\left(\mathrm{r}=0.370, \mathrm{R}^{2}=0.137\right.$, $P=0.019$ ).

\section{DISCUSSION}

The HR in the IDDP noticeably increased in the visual matching task phase, compared to the rest and control phases. There was a significant correlation between cognitive ability and the HR values in the visual matching task phase in IDDP. The response time and accuracy rate demonstrated significant negative and positive correlations with the HR, respectively.

Many studies reported that the HR during the cognitive processing phases increases, compared to that during the rest phase $[4,6,8,9]$. In addition, our study revealed that the HR increased in the visual matching task phase, compared to the rest and control phases. It is well understood that an increase in energy (e.g., glucose) supply leads to upgrade in the adenosine triphosphate (ATP) production within intervals of high requires. Increased production of ATP may enable improvements to be made in information processing during the performance of cognitive tasks. In order to metabolize the "fuel," the brain needs more oxygen [13]. Therefore, requires for oxygen increase during the cognitive processing period, and this induces an increase in the HR [4, 6, 8, 9]. Thus, an adaptive change in cardiovascular regulation probably related to cognitive efforts and emotional excitation plays a role of the independent factor in increase in the oxygen brain supply during the performance of the cognitive task.

Previous studies showed that as the HR value during the task phase increased, the cognitive ability increased in healthy young adults $[9,13]$. Our study also showed that there was a significant correlation between cognitive ability and the HR within the task phase not only in healthy people but also in IDDP. This means that the increasing HR intensified supply of oxygen by faster circulation of blood during the performance of a cognitive task, and this induced the improvement of cognitive ability in IDDP. The results of this study are in agreement with the data of our previous work [2] that the supply of hyperoxic air can positively affect the cognitive ability of IDDP via influencing the main parameters of autonomic regulation of the cardiovascular system.

The results of this and previous studies [2] may provide objective evidence that can be used for treating patients with cognitive problems that are obvious in IDDP.

Further studies are needed to be performed to examine the correlation between $\mathrm{SpO}_{2}$ and cognitive ability under normal air conditions, which may help to explain the effects of hyperoxic air on the cognitive performance change in the IDDP. This study would be further developed by examining the effect of hyperoxic air on the cognitive ability of IDDP using a brain analysis based on fMRI. From these studies, we could obtain improved scientific evidence toward clinical applications. 
Acknowledgment. This work was supported by the Konkuk University (South Korea).

The overall procedures and purposes of the experiments were explained to all subjects and their guardians, and their guardians' consent was obtained. All experiments were performed under the internationally accepted regulations and with the approval of the Institutional Review Committee.

The authors, H. J. Kim, M. H. Choi, I. H. Lee, S. P. Hong, N. R. You, H. S. Kim, D. W. Lim, and S. C. Chung, confirm that they have no conflict of interests.

Х. Д. Кім ${ }^{1}$, М. Х. Чой ${ }^{1}$, I. Х. Лі

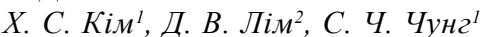

\section{КОГНІТИВНІ ЗДІБНОСТІ ТА РЕГУЛЯЦІЯ СЕРЦЕВО- СУДИННОЇ СИСТЕМИ У ЛЮДЕЙ 3 НЕДОСТАТНІМ ІНТЕЛЕКТУАЛЬНИМ РОЗВИТКОМ}

${ }^{1}$ Дослідницький інститут біомедичного інженерінгу, Коледж біомедицини та наук про здоров'я при Університеті Конкук, Чунгджу (Південна Корея).

${ }^{2}$ Університет Донггик, Сеул (Південна Корея).

Р е $з$ ю м е

Раніше ми вивчали позитивні впливи повітря, збагаченого киснем, на когнітивні здатності людей з недостатнім інтелектуальним розвитком (НIP). У нашій роботі ми досліджували кореляцію між показниками когнітивної активності в тесті візуальної відповідності та частотою серцевих скорочень (ЧСС) у таких суб'єктів в умовах дихання нормальним повітрям. У тестах брали участь 18 чоловіків (середній вік $28.7 \pm 5.0$ року) та 22 жінки $(35.5 \pm 6.9$ року) 3 оцінкою рівня інтелектуального розвитку $2.3 \pm 0.6$. Експеримент (загальна тривалість 7 хв) складався 3 трьох фаз: стан розслаблення (3 хв), контроль (2 хв) та тест візуальної відповідності (2 хв). Величини ЧСС у межах цього тесту порівняно 3 величинами в умовах розслаблення й контролю зростали. Показники когнітивних здібностей корелювали 3 величинами ЧСС; кореляція часу відповіді була негативною, а точності відповіді - позитивною. Отже, адаптивні зміни регуляції серцево-судинної системи, мабуть, пов'язані з когнітивними зусиллями та емоційним збудженням, є істотним фактором, який впливає на постачання мозку киснем у людей із НIP (як і у здорових людей). Результати нашої роботи узгоджуються з отриманими раніше свідоцтвами про те, що дихання повітрям, збагаченим киснем, позитивно впливає на когнітивні можливості людей із НІР.

\section{REFERENCES}

1. American Association on Intellectual and Developmental Disabilities (AAIDD). Definition of Intellectual Disability, http://aaidd.org/Accessed (2010).
2. H. S. Kim, M. H. Choi, H. J. Kim, et al., "Changes in simple visual matching task performance and physiological signals of intellectually and developmentally disabled people due to administration of highly concentrated oxygen," NeuroRehabilitation, 32, No. 2, 687-692 (2013).

3. S. C. Chung, G. R. Tack, B. Lee, et al., "The effect of $30 \%$ oxygen on visuospatial performance and brain activation: An fMRI study," Brain Cogn., 56, No. 3, 279-285 (2004).

4. S. C. Chung, S. Iwaki, G. R. Tack, et al., "Effect of $30 \%$ oxygen administration on verbal cognitive performance, blood oxygen saturation and heart rate," Appl. Psychophysiol. Biofeedback, 31, 281-293 (2006).

5. S. C. Chung, J. H. Sohn, B. Lee, et al., "The effect of transient increase in oxygen level on brain activation and verbal performance," Int. J. Psychophysiol., 62, 103-108 (2006).

6. S. C. Chung, J. H. Kwon, H. W. Lee, et al., "Effects of high concentration oxygen administration on n-back task performance and physiological signals," Physiol. Meas., 28, No. 4, 389-396 (2007).

7. S. C. Chung, B. Lee, G. R. Tack, et al., "Physiological mechanism underlying the improvement in visuospatial performance due to $30 \%$ oxygen inhalation," Appl. Ergon., 39, 166-170 (2008).

8. S. C. Chung, H. W. Lee, M. H. Choi, et al., "A study on the effects of $40 \%$ oxygen on addition task performance in three levels of difficulty and physiological signals," Int. J. Neurosci., 118, 905-916 (2008).

9. S. C. Chung and D. W. Lim, "Changes in memory performance, heart rate, and blood oxygen saturation due to $30 \%$ oxygen administration," Int. J. Neurosci., 118, 593-606 (2008).

10. S. C. Chung, G. R. Tack, M. H. Choi, et al., "Changes in response time when using oxygen inhalation during simple visual matching tasks," Neurosci. Lett., 453, 175-177 (2009).

11. M. C. Moss and A. B. Scholey, "Oxygen administration enhances memory formation in healthy young adults," Psychopharmacology, 124, 255-260 (1996).

12. M. C. Moss, A. B. Scholey, and K. Wesnes, "Oxygen administration selectively enhances cognitive performance in healthy young adults: A placebo-controlled double blind crossover study," Psychopharmacology, 138, 27-33 (1998).

13. A. B. Scholey, M. C. Moss, N. Neave, and K. Wesnes, "Cognitive performance, hyperoxia, and heart rate following oxygen administration in healthy young adults," Physiol. Behav., 67, 783-789 (1999).

14. E. J. Sung, B. C. Min, H. J. Jeon, et al., "Influence of oxygen rate on driver fatigue during simulated driving," Kor. J. Sci. Emotion Sensibility, 5, 71-78 (2002).

15. R. Winder and J. Borrill, "Fuels for memory: the role of oxygen and glucose in memory enhancement," Psychopharmacology, 136, 349-356 (1998).

16. E. D. Burgund, H. M. Lugar, B. L. Schlaggar, et al., "Task demands modulate sustained and transient neural activity during visual-matching tasks," NeuroImage, 25, 511-519 (2005).

17. J. Driver and G. C. Baylis, "Edge-assignment and figureground segmentation in short-term visual matching," Cogn. Psychol., 31, 248-306 (1996).

18. S. Pollmann and M. Maertens, "Shift of activity from attention to motor-related brain areas during visual learning," Nat. Neurosci., 8, 1494-1496 (2005). 